\title{
A MAGYAR REGIONÁLIS TUDOMÁNY ÉS AZ EURÓPAI REGIONÁLIS TUDOMÁNYI TÁRSASÁG: VÁLSÁG ÉS MEGNYUGTATÓ MEGOLDÁS ${ }^{1}$
}

\author{
(Hungarian Regional Sciences and the European Regional \\ Science Association: Crisis and Reassuring Solution)
}

\section{VARGA ATTILA}

A regionális tudomány számára a 2003-as esztendő jubileumi év volt: a novemberi philadelphiai világkonferencián a még mindig fantasztikusan aktív alapító, Walter Isard részvételével a tudomány létrejöttének ötvenedik évfordulóját ủnnepelte. Itthon mi is jubiláltunk: a magyar regionális tudomány októberben Pécsett megrendezett seregszemléjén a hazai regionális kutatások egyik fellegvárának, az MTA Regionális Kutatások Központja Dunántúli Tudományos Intézetének hatvanéves fennállására emlékeztủnk. A két jubileum egybeesése szimbolikus értékủ azáltal, hogy az a magyar regionális tudomány kezdettől fogva érvényes nemzetközi beágyazottságára utal. Sajnálatos módon az utóbbi néhány év során nemzetközi beágyazódásunk egyik lényeges instrumentuma, tagságunk az Európai Regionális Tudományi Társaságban (ERSA), igen komoly veszélybe került. E rövid beszámoló e veszély elhárítására az utóbbi két év során néhány kollégámmal egyuutt megtett, és pár hónapja sikert elért lépéseinkkel ismerteti meg az olvasót.

Az ERSA az európai országok regionális kutatóit integráló szervezet. Évente megrendezett kongresszusain előadások százai hangzanak el, az ottani személyes találkozások meghatározó jelentőségủek a közös kutatási projektek elindításában, azok fenntartásában, tanulmányok, könyvek születésében, nyári szemináriumai pedig a fiatal kutatók orientálásában játszanak fontos szerepet. A személyes kontaktusok mellett a szervezet web oldala és rendszeresen megjelenó hírlevele biztosítja az információk folyamatos áramlását a tagok körében. A magyarországi regionális tudomány képviselői már a kezdetektől fogva jelentős aktivitást mutattak az európai szervezetben, amit talán a Budapesten megrendezett ERSA kongresszus fémjelez leginkább.

Az ERSA alulról épủlő organizáció, melynek alapegységei a tagállamok regionális tudományi szervezetei, melyeket nemzeti szekcióknak neveznek. A nemzeti szekció-beli tagság automatikusan ERSA tagságot is jelent. Az ERSA legfőbb finanszírozási forrása a nemzeti szekciók által évente rendszeresen befizetett tagdíj. A magyar szekciót már a kezdetektől fogva a Magyar Közgazdasági Társaságon (MKT) belul mủködő Regionális Gazdasági Szakosztály szervezte. A nyolcvanas, illetve a kilencvenes évek elején mutatott (és régebbi külföldi ERSA-tagok számára is mindmáig emlékezetes) eröteljes nemzetközi és hazai aktivitás a kilencvenes évek második felére jelentỏsen megcsappant. Az ERSA magyar szekciójának válságát az évekig be nem fizetett tagsági díj jelzi talán a leginkább. Mindezek a válság- 
Varga Attila : A magyar regionális tudomány és az Európai Regionális Tudományi Társaság: Válság és megnyugtató megoldás

jelek természetesen az ERSA vezetőségének figyelmét is a magyar szekció felé fordították. Mivel a helyzet évekig nem változott, ezért az ERSA vezetősége 2001-ben úgy döntött, hogy a magyar szekció tagságát felfüggeszti.

A felfüggesztésről két kollégám, Andrés Rodríguez-Pose (az ERSA fötitkára) és Günther Maier (ERSA vezetőségi tag) tájékoztatott a 2001-es zágrábi kongresszuson. Sajnálattal közölték a tényt, és próbáltak meggyözni arra vonatkozólag, hogy valamilyen módon müködjek közre abban, hogy a hazai folyamatokat olyan irányba tereljük, ami a felfüggesztés megszünését eredményezi. Ez a magyar szekció „feltámasztását", annak újra aktivizálását jelentené természetesen.

Hazatérve kapcsolatba kerültem Horváth Gyula és Lengyel Imre kollégáimmal, akikkel megosztottam a magyar szekció problémáját, és javasoltam, hogy próbáljunk valamiféle megoldást találni. Mivel nagyon úgy tünt, hogy a magyar szekció hagyományos szervezetén, a MKT Regionális Gazdasági Szakosztályán keresztül nem lehetséges az áttörés, megszületett a döntés, miszerint új organizációt kell létrehozni a hazai regionális tudomány integrálására. A szervezés oroszlánrészét Horváth Gyula vállalta magára. Rövidesen, 2002 február végén, megalakult a Magyar Regionális Tudományi Társaság (MRTT) és annak elnökségét is megválasztottuk (elnök: Horváth Gyula, tagok: Illés Iván, Lengyel Imre, Nemes Nagy József, Varga Attila, póttag: Lados Mihály). A Társaság céljai között a következök szerepelnek:

- szakmai fórum biztosítása a regionális tudomány hazai mủvelői számára

- bekapcsolódás a regionális tudomány nemzetközi szervezeteibe

- híd létesítése a tudomány hazai és nemzetközi fórumai között

- kapcsolatok kiépítése a regionális tudomány kutatóhelyei, felsőoktatási intézményei, valamint a regionális politika alakítói, gyakorlati megvalósítói között

- a hazai regionális kutatások támogatása, valamint azok eredményeinek terjesztése, felhasználása

- a regionalizmus és a decentralizáció európai eszmeiségének terjesztése.

A szervezet bejegyzése a hosszadalmas jogi procedúrák miatt 2002 decemberében történt meg. A tagtoborzás igen gyors és jelentős sikerrel folytatódik: mára már több mint 250 tagja van az új szervezetnek egyetemi, akadémiai, minisztériumi, önkormányzati, regionális ügynökségi szakemberekböl. 2003 októberében a Társaság első vándogyülését Pécsett rendezte, ahol az MRTT programja is elfogadásra került.

Az ERSA elégedettséggel vette tudomásul a magyarországi folyamatokat a 2002-es dortmundi konferencián, de a felfüggesztést nem oldották fel. Egyik legföbb aggodalmuk a régi és az új szervezet közötti viszony megoldatlansága volt. Korábbi tapasztalatok fényében tartottak a kettő közötti békétlenségről, amit az ERSA saját magára vonatkozólag is zavaró tényezöként értékelt volna.

A 2003-as finnországi kongresszuson végre megtörtént az áttörés: a Magyar Közgazdasági Társaság főtitkára, Halm Tamás által küldött hivatalos levél, melyben a magyar regionális tudomány hazai szervezésének feladatáról az MKT sajnálattal lemond, és egyben sok sikert kíván az MRTT-nek, végleg megnyugtatta a kétkedőket. 
Varga Attila : A magyar regionális tudomány és az Európai Regionális Tudományi Társaság: Válság és megnyugtató megoldás

Tér és Társadalom 18. évf. 2004/1. 155-157. p.

TÉT XVIII. évf. 2004 แ 1

A pécsi vándorgyưulés ténye és annak programja, valamint az ország méretéhez képest szokatlanul nagy taglétszám garanciát adott arra vonatkozólag, hogy a hazai regionális tudomány szerveződése újra biztosított.

2003 szeptemberétől tehát az MRTT-t elfogadták az ERSA hivatalos magyar szekciójaként. Mindez a több éves méltatlan helyzet megszünését jelenti. Az októberi vándorgyúlésen tehát nemcsak a hazai regionális kutatások egyik legjelentösebb intézményének megszületését, de a tudomány müvelőinek az egyik legfontosabb európai szervezetbe való hivatalos újrafelvételét is ünnepelhettük.

\section{Jegyzet}

${ }^{1}$ Az eredeti szövegben tett pontosításokért Horváth Gyulát illeti köszönet. 